\title{
Women Empowerment for a Holistic Development in Nigeria
}

\author{
Chika Euphemia Asogwa \\ Department of Mass Communication, Kogi State University \\ Anyigba, Kogi State, Nigeria \\ Tel: 234-8-130-047-065Ｅ-mail: euchika@yahoo.com
}

Received: January 16, 2012

Accepted: February 20, 2012 Published: June 1, 2012

doi:10.5539/res.v4n2p138

URL: http://dx.doi.org/10.5539/res.v4n2p138

\begin{abstract}
Women empowerment as a concept has been related to development, democracy and all kinds of social wellbeing. Nigeria like most African countries is a patriarchal society, where men holds sway and lays down the rules. This paper affirms the need for women empowerment for a holistic development in Nigeria. The paper took off identifying the duality and complementarity in nature. The paper reveals the origin of creation of both man and woman which by pronouncement of the creator, God, was essentially on the basis of complementing each other, which means that the man and woman supposed to be seen as equal. Apart from the theory and counter theory of gender as elaborated in the paper, the physical differences between the masculine and feminine gender, the paper highlights the activities of the famous feminist radical activists of the early 60's and their ideologies. The various struggles for liberation of the feminine gender from the masculine domination are discussed. This paper compares the Nigerian woman of pre-colonial era and the present day Nigerian woman in franchise, financial responsibility etc. A figurative evaluation and analysis of the rights and privileges enjoyed by the Nigerian woman in the early post colonial era up to the present day situation is also mentioned. Finally, this paper emphasized the role of the media in women empowerment for a holistic development in Nigeria. In its role in empowerment the media has a hegemonic function and it is in addition seen as an agent of socialization.
\end{abstract}

Keywords: Nigeria, Women empowerment, Development, Complementarity, Media

\section{Introduction}

\subsection{Duality and complementarity in nature}

Mother nature perchance, is a symphony of interaction and at times, of a blending of polar opposites. Day and night intermingle on the twighlight of dawn and dusk, light and darkness alternate, cold and heat blend in a wide range of different degrees, round and round, rolls the different seasons fusing into one another and bedecking the year with variety of gaiety. It would not be too far from the truth then, to postulate that Mother Nature survives on a complementary orchestration of different and diversified units in its progression. I feel that a philosophic gleaning of such interactivity in nature finds a gleaming expression in the Hegelian dialectics.

In his analysis of ideological, historical and philosophical progression, Frederick Hegel postulated the famous Hegelian dialectics. Though he never used the terms himself, Hegel's dialectics is often simply surmised in the triadic interaction of the thesis in conflictual reaction to the antithesis, birthing an inevitable synthesis. Hegel conceived the whole of nature as a "continual process of becoming... All things contain contradictory sides or aspects, whose tension or conflict is the driving force of change and eventually transforms or dissolves them." For Hegel, the real is the absolute, this absolute he conceives as a 'dynamic process,' as 'an organism of multiple parts' but however, 'unified in a complex system'(Hegel, 1994:331). While not delving into the depths of the difference demarcating the so termed idealist dialectics in Hegel and material dialectics of Marx, a common denominator in both schools is the presence of an obviously conflictual or subtly complementary interaction of composite opposites. The example of dialectics is by no means relegated to the philosophic parlance. Such a theorem of complementarily is overt in the progression of modern day media.

One of the most insightful scholar of contemporary communication and its cultural impact Marshal McLuhan, in his designation of the part of modern media after a most astute delineation of the hot and cold media, proposed 
his philosophy of the convergence of the media under the hybrid energy. According to McLuhan (1994:55), the 'hybrid of two media is a moment of revelation from which new form is born.'

\subsection{Diversity and complements in human nature}

The creation of man and woman is Common to most cosmogonies. However, the multiplicity and myriads of myths not withstanding, complementarity of different units finds its explicit expression in the creation of humanity. This however, does not negate the fact that some creation myths represent the woman as subservient to the man. This forum however, enjoys a common credo; as such, I shall recourse to its creation tale.

'Male and female he created them,' the bible simply states (Gen 1:27). Without resorting to an exaggerated exegesis, suffice to say that the simple articulation male and female ipso facto entails and expresses some difference. At the lowest level of argumentation, in spite of the plethora of thesaurus, none equate 'man' as a synonym to 'woman.' Though man was created and immersed in a sea of creatures, scriptures does not mince word in defining man as lonely (Gen 2:20). And to stay this solitary emptiness, the creator in his wisdom declares, "It is not good for man to be alone, I will make him a helper fit for him" (Gen 2:18). According to Pope John Paul 11, "the creation of woman is thus marked from the outset by the principle of help: a help which is not one-sided but mutual." This 'help' the Pope noted has no reference to 'acting in time but a state of being'. He further added "Woman complements man just as man complements woman: Men and women are complementary. Womanhood expressed the "human" as much as manhood does, but in a different and complementary way" (John Paul 11, No. 7). Elaborating further on the command to procreate and perpetuate the human species (Gen 1:28), the Pope emphasized the fact that 'man and woman alike share equal responsibility from the start.' (John Paul 11, (a) no 8). The woman is another "I" in a common humanity. (M. d. 6). This biblical foundation furnishes us with an 'essential equality of man and woman'. In the anthropology of John Paul II, the unity of the two (man and woman) implies that both are called from the beginning not only to exist side by side but they are called to exist mutually complimenting another $(\mathrm{m} \mathrm{d} 7)$. The primal bi-polarity of the male and female is the primordial dialectical relationship imaging the communion of the trinity and patterning a paradigm forever in human relationships of love, marriage, family and also at the solid foundation of the society as a whole.(Guzman Carriquiry, 2006: 181).

\section{Counter Theory of Gender}

The uni-duality of man and woman epitomized in the Christian anthropology has come under fiery attack in recent times. More so, this attack is rendered more grievous, perpetuated in the name of liberation of the feminine by renown feminist.

There have been two strong waves in the promotion of feminism. The first is the suffragist movement which began in $18^{\text {th }}$ century headed by persons like Mary Wollenstonecraft (1759-1799). This movement panted for the active and equal participation of women in society. Like a being whose desire has been satiated and whose thirst assuaged, it slept the sleep of a fulfilled dream. The second wave which arose under the cultural stimulus of the social revolution and civil right march in the $60 \mathrm{~s}$ had a radical and boisterous nature. It aggressively advocated the sexual liberation of women without bounds. It favored the rise of organizations such as planned parenthood of Margaret Sander, organization for women with Betty Freidan: as first president and author of the feminine mystique, Susan Browsmiller (author of feminism), Gloria Steinem and Germain Greer. As a motion to liberate the woman from the shackles of biological determinism, this movement generated the use of term gender. This term was used by Ann Oakley and other feminist in the 70s. Under gender feminism, Sexual differences tended to be downplayed and denied under the periscope that there are just mere historical and cultural conditionings enslaving the woman in pseudo maternity and limiting maternal obligations.

According to Lucetta Scaraffia "We have moved away from two different but complementary roles, each needing one another, to a kind of 'unisex' role, more akin to the male role, with the result that complementarity has been replaced by competition between men and women...it is obvious that when, in the name of individual freedom, the bulkheads separating sex-determined roles collapsed, women chose to take on the role which enjoyed the highest social and financial prestige: the male role, abandoning the woman's place. (Lucetta Scaraffia 2006:15-18) According to the Director of the "San Luigi dei Francesci" Cultural Center in Rome, this is ushering in "breakdown in many fields of every distinction between men and women, to the point of introducing the theory of gender, which holds that a person can decide at will whether to be a man or woman'. (Vincent Aucante, 2006:23)

This radical feminism has exerted an immeasurable influence on the western world provoking nothing short of an 'anthological cataclysm'. feminism occasion a cultural chaos and 'shifted western culture away from the family to the couple, from the spouse to the partner, from the person to the individual, from love as a gift to 
egotistical self seeking, from happiness to pleasure and from free-giving to possession (Marguerite Peeters, 2006:75). Still tracing the track of the impact of the radical feminism on modern culture, Giulia Paola Di Nicola and Attilo Danese: universities professors and founder of Centro Internationale Ricerche Personaliste, Teramo, added that outside the rising rate of divorce and the failed marriages, "we are also witnessing an increase in the numbers of disturbed identities( increased violence, homosexuality, frigidity, anorexia and bulimia, a rise in female prostitution and corresponding increase in demand for it from men.( Giulia Paola Di Nicola, 2006: 155). John Paul II with deep insight tagged this 'masculinization of the feminine' (John Paul II (b) No: 7). It is like the prophecy of John Paul II is coming through. He had warned that woman under no pretence of liberation should appropriate characteristics contrary to their own feminine originality. This may not lead to fulfillment but deform and lose what constitutes their essential richness of the woman. (D. M. No 7). Forty years after women bought the feminist ideology of the 60s, Karma Swanson-journalist and co-editor of the 'mujernueva- opined that women are reconsidering their stance as the price they have to pay in terms of 'instability of relationship, more work, depression and frustrations, women are twice today to be single mothers. Twelve million American women suffer depression, anxiety and disorder and 2.7 million women suffer from alcoholism.' Simply she concludes feminism under the umbrella of masculinization of the woman simply no longer sell (Karma Swanson 2006: 43). We may say then, that there is a gradual, reluctant but steady retracing of steps to the Christian anthropology.

\subsection{Duality and diversity}

In his letter to women, Pope John Paul II stated very clearly the existence of a diversity of the nature and roles of the woman as distinct from the man. In his words, "woman and man are marked neither by a static and undifferentiated equality nor by an irreconcilable and inexorably conflictual difference. Their most natural relationship, which corresponds to the plan of God, is the "unity of the two," a relational "uni-duality," which enables each to experience their interpersonal and reciprocal relationship as a gift which enriches and which confers responsibility. (No 8). Further on in the same letter, the pope states that this diversity does not include prejudice to the woman. Provided this diversity is not the result of an arbitrary imposition, but rather an expression of what is specific to being male and female (No. 11).

\subsubsection{Physical differences}

One of the arenas in which the difference between man and woman is most prominent is in the camp of the physical difference. Not Even the most avowed enemy of sexual discrimination can deny that men and women have different physical make up. The physical differences are rather too overt to be explained away in the logic of nurture and culture. I subscribe very much to the delineation of the physical differences by Nicholson (1993:40). Some of these physical attributes can really be measured: anatomical sizes are not philosophical convolutions but tangible facts. Bigger torso and muscular build are hall marks of men. Man has a thicker and stronger skull compared to the woman. While the woman is more endowed with 'four times as many brain cells connecting the right and left side of their brain'. This implies that women have more access to both sides of the brain while men rely more often on the left brain to solve their problems. Women can focus on more than one problem at one time and while man tends to focus on one at a time. Men are more endowed with larger lungs, more powerful hearts and more hemoglobin. This implies that men can take in more oxygen, pump that oxygen round the more easily. It's not surprising then that the average male has more stamina than the woman (Nicholson, 1993:41). However because of the continuous chemical and hormonal fluctuations in her body, the woman has muscles which can survive more changing environ in which hormonal levels rise and falls. According to Nicholson, when taken for jogging, the heart of the untrained man pumps 100 milliliters of oxygenated blood while that of the woman makes 75 milliliters. After training, the man pumps 160 milliliters against she, 110 milliliters. A similar difference exists between the male and female rate of extraction of oxygen. The man extracts 50 milliliters before training and 84 milliliters after training while the woman extracts 40 milliliters of oxygen before training and 70 after training (Nicholson, 1993:45). While a trained woman may outrun the untrained man, equating a trained man with a trained woman, the man has more to his side on physical strength. The difference between men and women provides functional advantage. Strength could be nature's 'gift to man but women have a definite edge when it comes to survival'. The slow ability to consume oxygen becomes a life saver in the eventuality of scarcity of food and the greater fat in the woman becomes a resource in the day of drought. On the same plain of survival, it is worth noting that men are more vulnerable physically than women. The ratio of conception is between 107 to 124 Males to every 100 females. But the male embryo has greater tendency to spontaneous abortion and other hazards like asphyxiation. Prenatal complications are more common in boys. Men are more likely to suffer occupational hazards and accidents than women. While women are more likely to suffer from cancer of the reproductive organ and hormone related 
diseases like diabetics, men are more susceptible to other forms of disease like heart attack, strokes and disorders of the respiratory system like bronchitis and emphysema. The balance of population which favored the baby boy is overturned in old age so that at 70 there are two women for every surviving man (Nicholson, 1993:55). The difference of the sexual organs is another obvious and major one.

According to the psychoanalytic school of thought, the profound difference that exists between the man and the woman is a predisposition and predilection that has its font in the human anatomy. For this school of thought and based on the experiments of Erik Erickson, the girls are thought to emphasize the inner and the boys' outer space. To prove this point, Erickson holds that men's 'accomplishments in the conquest of geographic space and of scientific fields and in the dissemination of ideas speak loudly for themselves and confirm traditional values of masculinity' (Erikson, 1968; 273).

\subsubsection{Problems}

Problem solving means different things to men and women. While for women discussion and sharing a problem is an opportunity to explore, and deepen relationship with the partner, for men it is an occasion to demonstrate competence. While for the woman how the problems are solved has more significance for man it is solving the problem effectively. While the man tends to distance himself from the problem and has a linear approach of one problem at a time overlooking subtleties, the woman has a more collective and interconnected view of problems, with ability to greater multiple processions.

\subsubsection{Memory}

While women seem to have an enhanced capacity to remember event with strong emotional content, men tend to recall using strategies that depend on reconstructing the experience of terms of elements or activities that took place. Men remember more events associated with strong competition or physical activity. What defines a valid relationship for men differs from women. Men feel greater proximity to their partners in 'shared activities, e,g sports, competition, outdoor or sexual activities that are physical, women are more at home through communication, dialogue and intimate sharing of experience, emotional content and person perspectives.

According to a Nigerian author Chinweizu, in this delineation of the male and female powers he writes, whereas "male power tends to be confrontational and direct, female power tends to be subtle, manipulative and indirect. Whereas aggression is the hallmark of male power, manoeuvre is the hallmark of female power. And where man is the great physically aggressor, the female is the great psychological manoeuvre." In the face of resistance, the male power 'barks, command and pummels' female power 'whispers and manipulates' (Chinweizu, 1990: 45).

In all these probable delineation of traits, I lean more to the diversity of roles as presented by the Pontificium Consilium Laicum. According to the compendium of resources garnered by the Consilium at the end of one of its seminar, this seminar based its delineation of roles and differences in predisposition as offshoot of the hermeneutics of the body. According to this document " the art of deciphering and responding to the signals sent out by the body gradually builds up our destiny across the years ... There is no doubt that the two genders, through their bodies, express a different tonality in the way they exist in the world".(Giullia Paola 2006: 157). The horizon of reciprocity in the family one of the papers of this seminar delineated the difference between man and woman in five camps:

\subsubsection{Relationality and self affirmation}

There is a paradigm of meanings that issues from the procreative process in women. Certain anatomical attributes peculiar to the woman predisposes her as "a being for". "The umbilical cord which unites the mother and child, and makes them interdependent, disposes them not to lose sight of the integral nature of the person and environmental contexts overcoming false dichotomies, fragmentation and hierarchisation..." (Guilia di Paola, 2006; 158). From this stand point, one may infer that the female has more predilections for that which 'strengthens bonds' and the promotion of integration. The masculine side to this preference for self assertiveness, 'the tendency to externalize and give visibility to one s own potential'. (Giulia di Paola, 158)... As such, that self confidence and self esteem in one's ability 'are therefore valid prerequisites for guaranteeing personal maturity and strengthening the man's capacity to relate to others, though it is not an exclusive preserve of men.

\subsubsection{Limits and combating limits}

The woman has more keen and acute sense of personal limitations: a responsible awareness that has its foundation in her experience of life from her body. One can hardly determine the metabolism of one's with certitude. It is particularly important for girls to fully comprehend 'this limitation in order not to simply endure the rhythm of their own body'. This knowledge seems to enkindle in women a greater appreciation of interdependence. For the man, from the experience of his physical attribute of strength, man seems prone to fight 
and struggle against limitations engendering a certain proneness to 'a sense of duty and to defend oneself and one's territory'.

\subsubsection{Care of life and dynamism of life}

The woman seems to have a certain proclivity to the care of life arising from her experience of maternity. This is confirmed in the feminine ability to nurture through the placenta, breast feeding, cooking and distribution of food, accompanying loved ones in difficult moments, care of new born babies not in the imposition of rules of conduct, but of offering a safe world, mothering, encouragement, looks that speaks of appreciation and love, instilling confidence and supporting the hesitant steps of growing up (Giulia di Paola, 2006; 163). In the care of a being so fragile as a baby by the loving hands of a woman, the woman "experiences a transition from being for herself as an individual to being with and for someone else". This seems to prepare the woman as person with greater tendency to foster relationship (Giulia di Paola, 2006; 163). No one denies the fact that caring is common to men and women, but it seems women develop a stronger affinity to what is fragile to the point of driving them to heroic acts. The male is more given to a 'typical vital dynamism'-taking delight in adventure and displaying curiosity in everything. According to this stand, man learns nurturing and fatherhood from motherhood (Guilia di Poala, 2006; 164 -167).

\subsubsection{Feminine flexibility and masculine normativity}

The woman has a stronger proclivity to relations. While she can obey rules within the confine of structures, she has a higher tendency to act against structural rules when 'essential values and affections are at stake.' Issuing from this tendency is 'necessary detachment from structures which makes it possible to reach out to people beyond bounds of their social status'. Applied to the religious life, 'they are less concerned with rules and institutions and more concerned with the spiritual, affective and mystical relationship with God' (Giullia di Paola, 2006; 167). The male counter part seems to be given more to 'organizing social life by producing new rules on a rational base to guide behaviour'. In a research conducted by Jean Piaget and Gilligan, the boys are more concerned with rules, while the girls are more interested in relationships in children games (Giulia di Paola, 168).

\subsubsection{The positive face of pain and determination to defeat evil}

The woman's experience of the pangs of pain at birth could be harrowing. At labour, the woman's body is 'overwhelmed with pain, it entails a laceration and separation. The cries of the mother and child "express both the celebration of the conclusion and the beginning of both pain and the triumph of life over death." (Guilia di Paola, 2006: 170). It is an experience of the motherhood of Christ. For Erickson, the woman is a "dolora" in a special way.(Erikson,1968; 284) The experience of pain instills in us and more so the woman-'whose body becomes a special sign of the mystery of life triumphing over death', that suffering is pregnant with the promise of greater joy. The man however, is opposed to enduring the pain; men tend to view pain as something to be overcomed and dominated as soon as possible. (Guillia di Paola, 2006: 171)

What we have tried to chronicle so far, is an adventure in the atomization of the very probable differences between men and women on the grounds of predilection but not of exclusive reserve, on the percentage of average rather than inclusive preserve. Each sex can and do from time to time transcend itself to feel and to represent the concerns of the other but this does not negate the presence of certain predispositions more peculiar to one sex. Having seen these differences, we may ask how do they co-exist?

\section{Diversity yet Mutual Complementarity}

Like diverse notes on the scale of music, the differences in man and woman works not so much to conflict as to complement. According to the document by the United States Conference of Catholic Bishops on man and woman, the conference attest clearly that though man and woman are different, they are equal and fulfill each other through their natural differences, "these differences are constructive and complementary the document noted (Document of Man and woman in USCCB). This complementarity according to Stanislaus Ryko (2006:7), is not limited to the physical but it is also ontological. 'it is only through the duality of the masculine and feminine that the human finds full realization' he emphasized.

There have been a tendency doting the part of history that tends to characterize the woman as weak because of the peculiarity of her predilections, this however is not true because in her so termed softness is her power. Neither is the woman therefore less active in society simply because her virtues are not those defined as champions. We however, cannot forget the hegemony of patriarchy that participates in the game of life and stands as the judge over what is worthwhile and not in the same game. 
According to John Paul II "In the sphere of what is "human", of what is humanly personal-"masculinity" and "femininity" are distinct, yet at the same time they complete and explain each other.(D. Mno 25). The personal resources of femininity the pope holds are certainly no less than the resources of masculinity: they are merely different'. (D m 10) for the pope likewise, marriage entails a form of subjugation but it is not a subjugation of sex to the other but of the spouses out of reverence for Christ, to one another

\subsection{Complementarity and development}

So far, we have tried to recognize the differences in composition and in perspective between the masculine and feminine while holding that these peculiarities complement one another. It is our believe, that the man brings his masculine charisma and perspective to bear in every field of endeavor where he is engaged. The woman likewise from the wealth of her feminine gifts brings a special feminine touch to bear in every place she may find herself. As Erik Erikson would say, 'the woman is never not-a-woman'. Resonating on the same frequency Pope John Paul II noted with regards to the feminine specialty that "into the heart of the family and then of all society, you bring the richness of your sensitivity, your intuitiveness, your generosity and fidelity. (John Paul II No 2). The same John Paul II defined this peculiarity of the woman as the "feminine genius".

The balanced development of any society or nation then, involves harnessing the diverse talent of and equal participation of all members either masculine or feminine. The United Nations Organization states this so simple and yet so succinct. "The full and complete development of a country, the welfare of the world and the cause of peace requires the maximum participation of women as well as men in all fields ( $\mathrm{UN}$, declaration on the elimination of the discrimination against women. 1967).

To buttress this point, let us take for an analysis, the upbringing of a child. Children seem to seek different things from their parents: security from their mother, friendship and stimulation from their father. (Nicholson, 1993;156). Owing to this, researchers have concluded that 'paternal deprivation is just as serious a threat to children's welfare as maternal deprivation. (Nicholson, 1993; 158): a child who suffers from such a deprivation may die from what he calls marasmus adjoined Eric Ben, the father of transactional analysis.

While the nation might not die from a deprivation of the paternal or maternal contribution, it is natural to assume that it will diminish and never achieve its proper greatness. Opinions are generally agreed that a superabundant predominance of the public forum with the masculine gender suffocates the feminine genius from manifesting and contributing to the wealth of the nation.

Mercy Oduyoye (1986:121) holds that, 'The female principle and perspective have not been explored sufficiently while the "male" has been over used to the point of stagnation, thus plunging us all into a status quo that defies analysis.

'Women's dignity has often been unacknowledged and their prerogatives misrepresented; they have often been relegated to the margins of society and even reduced to servitude. This has prevented women from truly being themselves, and it has resulted in a spiritual impoverishment of humanity'. (Letter to women no. 3). It is the informed recommendation of this paper therefore, that progress of a nation will be on a speedy plinth if the charisma of its male and the genius of its female are equitably harnessed for the good of the nation.

\subsection{Complementarity in Nigeria}

Under this paragraph, we are seeking to glean the pattern of the presence of complementarity on the Nigerian soil.

Though Nigeria was patriarchal in linage, the woman enjoyed a greater privilege under the pre-colonial rule. Ogunsheye observed that the woman had important jobs. "A woman who was without a craft or trade, or who was totally dependent on her husband, was not only rare, but was regarded with contempt" (Effa Etoh, 1992). Effa noted the fact that most often, the women carried out separate functions from the men and these functions were fully complementary (Effa Etoh, 1992). The pre-colonial Nigerian woman was strong and participated in the progress of her family and community according to her own mode. They held important administrative offices in some cultures. In pre-colonial Bornu, they held the office of the Megira (Queen mother). In ancient Zaria the foot print of queen Bakwa Turuku and her daughter Queen Amina remains indelible.

Most historians term the colonial era as the thief of the woman's dignity in Nigeria. A proposition which may not be far from the truth as the colonial masters imposed its patriarchal pattern on already existing patriarchy doubling the effect. According to Cheryl Johnson "Colonial patriarchy imposed on indigenous male domination exacerbated the inequalities between women and men and turned the pre-colonial sexual division of labour into the ghetoizatioin of women in the economy (Cheryl Johnson, 1986:238). 
The 1920 and 1940 riots in Aba, Owerri, Calabar, and Abeokuta were more of reactions against too much domination. Women were denied large scale loans which was necessary for participating in colonial export economy. Women were denied franchise and very few were allowed political and administrative offices. The presence of women in administration began around 1950 with the appointment of women like (Mrs) Olufunmilayo RansomeKuti (appointed into the Western Nigeria House of Chiefs); Chiefs (Mrs) Margaret Ekpo and Janet Mokelu (both appointed into the Eastern Nigeria House Of Chiefs).( Effa Etoh, 1992). Franchise was first granted to women in the east in the same 1950. These factors adversely disadvantaged the woman.

\subsection{Mise en scene of modern Nigeria}

The first days of post colonialism was not too different. In the ratio of $100 \%$ of the workforce, women constituted only $6.9,8.7 \%$ in 1970 arising to $12.6 \%$ in 1980 (Effa Etoh, 1992). Only 3\% of Nigerian women were in the countries parliament (Omaliko, 2001; 45). According to 1995 estimate, $28.18 \%$ of Nigerian women were in the active labour force compared to the $51.13 \%$ of men (Omaliko, 2001; 43).

The participation of women in the public forum commendably has continued to increase in Nigeria. It is worth noting that president Goodluck had elected a couple of females into high positions, however much remains to be done.

According to 1998 census, the population of Nigeria was 120.8 million people. The document furnishes us the fact that women made $50.7 \%$ of the population but with regard to the workforce, they make only $36 \%$. While the percentage of men without job was $2.8 \%$, the percentage of women without work was $3.4 \%$. With regards to literacy, the document records $52 \%$ of women as against $70 \%$ of men. $36 \%$ of women live in condition of polygamy while $20 \%$ of women suffer violation in adult relationship. With regards to female circumcision, $50 \%$ of women have undergone this abuse. Whereas in the educational parlance, while there is $100 \%$ registration of boys in primary schools, there is only $70 \%$ of girls and for the secondary school, the ratio is $58 \%$ of girls to $60 \%$ of boys.

The fact that the woman is disadvantaged in the above data is clear. The frequency of the girls in schools and women in places of jobs is far less in the above data. More so there are other subtle ways the woman is denied an equal personality. According to an Igbo saying Di Bu ugwu nwanyi (a woman's dignity in society is her husband) (Omaliko 2001: 41). Women and girls in Nigeria are subjected to violence by members of their families and their communities. Worst of all majority of these acts of violence are perpetuated by husbands, partners and fathers. Such violence is all too frequently excused and tolerated, not denounced, and the Nigerian government fails to investigate and punish (violence in Nigeria). According to Okogie, the Nigerian women are 'excluded from power, exploited at all levels and derided most of the time by society (Okogie, 2002:60).

Currently under the present presidential system, out of 32 ministers only 7 are women; it may interest us to know that this female persons in public office are doing rather marvelously.

It would be right then to say that the Nigerian woman is marginalized in the field of public life, families and education and there is no proper effectuation of complementarity.

One of the new altars where the image of the African woman is sacrificed is that of the media especially the very fecund and prolific Nollywood. The media representation tends to depersonalize woman and reinforce traditional prejudice. More so most of the media image does not reflect the changing attitudes but promote unfounded stereotypes.

\subsection{The effect of the absence of women}

Nigeria is like a baby estranged succulent embrace, starved of the nurturant milk and deprived of the soothing caress of his mother, can he grow? Surely it will, but a stunted growth. The stark paradox between Nigeria's wealth of resources and personnel is but a strong indication that something is wrong. The economic, social and political ambit of every nation is determined by the people that flood its streets. The personality and predisposition of a man or woman is more often molded in the early years of life. Hence the truth of Chinweizu that who ever trains a child in its first years shapes it for life (Chinweizu 1990:140). It is exactly this period of life that most children stay under the aegis of their mother. It has further been noted that that declines in infant mortality, improved nutrition and medical care as well as lower fertility rates were functions of a mother's level of ability.

It therefore follows that denying the woman folk an inevitable position of equality in the podium of national development will leave a very negative imprint on the part of the nation's growth. John Paul II acknowledging this fact calls for an urgent need to achieve real equality in between men and women. He further opined that a greater presence of women in society will prove most valuable, for it will help to manifest the contradictions 
present when society is organised solely according to the 'criteria of efficiency and productivity', and it will force systems to be 'redesigned in a way which favours the process of humanization which mark the civilization of love'. (John Paul II. No 4)

\section{Empowering the Nigerian Women}

A better Nigeria in the vision of this paper can only be achieved with the proper equilibrium of the richness of its male attributes and the genius of its female citizens. To achieve this then, there is need for an empowerment of the woman in Nigeria.

Empowerment literally means to give power to, to give strength and confidence. According to Marguerite Peeters, it is a social engineering process sensitizing women to the inequalities. Empowerment seeks to strengthen women to take their proper place in 'taking decisions and exercising negotiating powers', make their voice heard, but be able to organise and influence the direction of social change, and create a just social and economic order, at the national and international level (2006:83).

This empowerment can only take place through a complementary contribution of both man and woman for the benefit of both.

\subsection{Chronicle of empowerment}

Much has been done to empower the woman to fulfil her destiny in the society of persons. Under the aegis of United Nations, a lot of conventions and conferences have been held to promote and empower the woman. From the conventions of the political right of women in 1952 through the world year of women in 1975, in which equality of the sexes was officially proclaimed by the UN, leading to the global conferences on women issues in Mexico -June to July 1975, with delegations from 133 states. The Mexican conference had a clear goal to promote equality of men and women and to foster the integration of women in the total development effort and to increase the contribution of women to the strengthening of world peace (Handbook for Legislation on violence against Women (2010,17-18). The fruition of this conference engendered the declaration of the decade of women from 1976-1985. The approval of the convention on the elimination of all forms of discrimination against women in 1979, the $2^{\text {nd }}$ global conference Copenhagen conference of 1980 which addressed employment, health and education of women, the third world conference in Nairobi 1985 to evaluate the decade of women and the fourth world conference on women which was held in Beijing from $4^{\text {th }}$ to $15^{\text {th }}$ September 1995 are no small milestones on the part of feminine empowerment.

On the local scenery of Nigeria, Okogie attests to the fact that governmental and non-governmental associations have made strong efforts to alleviate the plight of the discriminated Nigerian woman. Such groups as gender and action development, constitutional right project, women in justice programme, public enlightenment outreach programme for market women, women law and development centre, women in Nigeria, win, better life for rural women, catholic women organization, Nigerian association of women journalist. These organizations and many individuals are doing a lot to better the lot of the Nigerian woman.

However, one veritable vehicle of empowerment which this paper wants to recommend is the media of mass communication.

\subsection{The role of the media in empowerment}

Anthony Giddens may not be far from the truth when he declared that we live in an interconnected age in which people from around the globe participate in a single information order (2001:453). Indeed the world has become a global village as Marshal McLuhan predicted a phenomenon that owes its existence more than anything else to the media of mass communication.

The media has a hegemonic function, transversing the barricaded frontiers of nationality, permeating the impervious enclaves of homes and infiltrating the guarded and invisible terrain of the mind. The media by promoting loosely interrelated corpus of ruling ideas takes up an agenda setting function and the most pronounced agent of socialization. We can boldly refute the phrase 'the power is in the barrel of the gun with the 'influence is in the media of communication.

With such a hegemonic function, the media becomes a potent podium from which one can make or mar. Sad to note, the media has been used to downplay the role and personality of the woman on manifold front.

\subsection{Media and discrimination}

According to Eugenia Abu, a broadcaster with the NTA, the media in Nigeria promotes the ruling ideology of the land which is infused with patriarchy. The media in Nigeria therefore, reinforces the stereotype of a passive, dependent and subservient woman. (1997:208). In other instances, the media has sold a negative image of 
woman where the old and wrinkled woman becomes the image of a wizard, the gorgeous lady becomes the prostitute and the loving and caring wife becomes daft and unintelligent. A famous song played on the Night of a thousand laughs depict every woman and girl in Nigeria with a negative connotation, the Ibo girl as money monger, the Yoruba girl as dirty, the Calabar girl as wayward and incurable nymph, etc. Such stereotyping does more harm to the perception and acceptance of the woman in the public and private forum.

\subsection{Media for Nigerian women empowerment}

Stemming still from the hegemonic rule of the media, vehicles of mass communication can be put to positive use to promote the dignity, equality and genius of the woman as a strong counterpart in the progress of the community.

Such representation must eschew exaggerations even in the name of humour. Seek to give a more constructive view of the roles of the woman and man in the family and community building while setting a paradigm for younger girls. This implies ipso facto the censorship of the media and its content to see if it promotes the welfare of the nation or not.

The media can also be used to impact knowledge especially the literacy education of women. Educated women here have a strong role to play in the socialization of their fellow women. Women must gather their forces and voices together under organizations that can promote their interest.

As far as personal rights are concerned, there is an urgent need to achieve real equality in every area: equal pay for equal work, protection for working mothers, fairness in career advancements, equality of spouses with regard to family rights and the recognition of everything that is part of the rights and duties of citizens in a democratic state. (J.P.11 4)

The recommendations of the convention on the elimination of all forms of discrimination against women is imperative here, "By accepting the Convention, States commit themselves to undertake a series of measures to end discrimination against women in all forms, including:

- to incorporate the principle of equality of men and women in their legal system, abolish all discriminatory laws and adopt appropriate ones prohibiting discrimination against women;

- to establish tribunals and other public institutions to ensure the effective protection of women against discrimination; and

- to ensure elimination of all acts of discrimination against women by persons, organizations or enterprises."

Finally a quote from a famous psychoanalyst Erikson $(1968 ; 293)$ summarizes this paper, "there is something in woman's specific creativity which has waited only for a clarification of her relationship to masculinity (including her own) in order to assume her share of leadership in those fateful human affairs which so far have been left entirely in the hands of gifted and driven men, and often of men whose genious of leadership eventually has yielded to ruthless self-aggrandizement. Mankind now obviously depends on new kinds of social institutions which guard and cultivate, that which nurses and nourishes, cares and tolerates, includes and preserves.

\section{References}

Abu, E. (1997). Women in Broadcasting: An African Perspective in deregulation of broadcasting in Africa. Lagos: National broadcasting commission.

Aucante, V. (2006). In Pontificum Consilium Pro Laicas, Men and Women; Diversity and mutual Complementarity. Roma: Editrice Vaticana.

Cheryl, J. (1986). Class and Gender, a consideration of Yoruba women during the colonial period. In Robertson, C. \& Berger, I., Women and class in Africa (pp. 238). New York: Africana Publishing company.

Chin, W. Z. (1990). Anatomy of Female Power: A Masculinist dissection of matriarchy. Pero Press, Lagos, Nigeria Covention on the elimination of all forms of discrimination against women. [Online] Available: http://www.un.org/womenwatch/daw/cedaw/

Department of Economic and Social Affairs / Division for the Advancement of Women. (2010). Handbook for Legislation on Violence against Women. New York: United Nations Publication.

Effah, A. (1992). Women in the Development of Nigeria Since pre-colonial Times.

Erickson, E. (1968). Identity Youth and Crisis. New York: W.W. Northon.

Giddens, A. (2001). Sociology (4th edition). UK: polity press. 
Gwinn, R. P. et al. (1986). The New Encyclopedia Britannica (15 ${ }^{\text {th }}$ edition, Vol. 4, p. 63). Chicago.

Hegel, G. W. F. (1994). Enciclopedia della scienze filosofiche in compendio. Roma: Bari; Laterza.

John, P. II. (1998). Muliens Dignitatem, of the Supreme Pontiff John Paul II on the Dignity and vocation of women on the occasion of the Marian Year.

Luccetta, S. (2006). In Pontificum Consilium Pro Laicas, Men and Women: Diversity and mutual Complementarity. Roma: Editrice Vaticana.

McLuhan, M. (1994). Understanding Media, The Extensions of Man. London, England: MIT Press.

Nicholson, J. (1993). Men and Women: How Different are They?. USA; Oxford University Press.

Oduyoye, M. (1986). Hearing and knowing: theological reflections on Christianity in Africa (pp. 121). New York: Orbis books.

Okogie, M. (2002). The role of the Nigerian association of women journalists in improving the image of women in Nigeria. Masters Thesis. Pontifical Gregorian University, Rome.

Omaliko, J. (2001). The situation of women in the Igbo traditional Society: problems and solutions. Masters Thesis. Pontifical University of St. Thomas Aquinas, Rome.

Paola di, N., G., \& Attilio, D. (2006). In Laicas, P. C. P. (Ed.), Men and Women: Diversity and mutual Complementarity. Roma : Editrice Vaticana.

Peeters, M. (2006). In Laicas, P. C. P. (Ed.), Men and Women: Diversity and mutual Complementarity. Roma: Editrice Vaticana.

Stanislaw, R. (2006). In Laicas, P. C. P. (Ed.), Men and Women: Diversity and mutual Complementarity. Roma: Editrice Vaticana.

Tinubu, A. B. A. (2009). Violence against women: Nigeria, violence against women must stop. [Online] Available: http://web.amnesty.org/actforwomen/nga-180705-action-eng

United States Catholic Bishops Conference. (2003). Between Man and woman: Questions and answers about Marriage and Same sex Unions.

Wansbrough, H. (1985). The New Jerusalem Bible. New York, London: Doubleday; Darton, Longman \& Todd. 